\title{
Nitric oxide levels and endothelial nitric oxide synthase gene polymorphisms in Turkish women with idiopathic recurrent miscarriage
}

\section{Açılanamayan tekrarlayan gebelik kaybı izlenen Türk kadınlarnnda endotelyal nitrik oksit sentetaz gen polimorfizmleri ve serum nitrik oksit seviyeleri}

\author{
Ebru Öztürk ${ }^{1}$, Özcan Balat ${ }^{1}$, Sacide Pehlivan², Mete Gürol Uğur ${ }^{1}$, Yelda Özkan ${ }^{1}$, Tuğçe Sever², \\ Emine Namıduru ${ }^{3}$, Seval Kul ${ }^{4}$ \\ 'Department of Obstetrics and Gynecology, Faculty of Medicine, Gaziantep University, Gaziantep, Turkey \\ ${ }^{2}$ Department of Medical Biology and Genetics, Faculty of Medicine, Gaziantep University, Gaziantep, Turkey \\ ${ }^{3}$ Department of Biochemistry, Faculty of Medicine, Gaziantep University, Gaziantep, Turkey \\ ${ }^{4}$ Department of Biostatistics, Faculty of Medicine, Gaziantep University, Gaziantep, Turkey
}

\section{Abstract}

Objective: To determine whether endothelial nitric oxide synthase (eNOS) gene polymorphisms are associated with an increased risk for Idiopathic Recurrent Miscarriage (IRM) in the Turkish population and to evaluate the association between Nitric Oxide (NO) levels and eNOS gene polymorphisms in women with IRM.

Material and Methods: A total of 120 Turkish women were enrolled in this study in four groups. Of these, 30 women were first trimester pregnant who had IRM (Group I). Thirty healthy multipara women were in the first trimester of pregnancy with no history of abortion (Group II). Thirty women were non pregnant with a history of IRM (Group III). The remaining 30 subjects were healthy multipara nonpregnant women with no history of abortion (Group IV). DNA analysis of four groups were performed for the two polymorphisms using the PCR and/or PCR-RFLPs method and NO levels were measured spectrophotometrically.

Results: We observed statistically significant decreased NO levels in the pregnant patient group $(p=0.001)$ while elevated NO levels were measured in the non pregnant patient group $(p=0.004)$. We demonstrated that,while there was no significant difference in terms of VNTR 4/eNOS genotype, there was a marginally significant difference in terms of Glu298Asp/eNOS genotype frequency $(p=0.055)$ in patients with IRM in the Turkish population. We observed no association between NO levels and Glu298Asp/eNOS or VNTR 4/eNOS genotypes in any of the groups.

Conclusion: The Glu298Asp polymorphism of eNOS could be an intriguing susceptibility factor that modulates an individual's risk of IRM in Turkish population. Further studies to explain the role of the NO pathway in the pathophysiology of IRM are needed.

(J Turkish-German Gynecol Assoc 2011; 12: 234-8)

Key words: Idiopathic recurrent miscarriage, nitric oxide, gene polymorphisms

Received: 28 August, 2011

Accepted: 11 September, 2011
Özet

Amaç: Türk toplumunda Endotelyal Nitrik Oksit Sentetaz (eNOS) gen polimorfizmlerinin açıklanamayan tekrarlayan gebelik kayıpları (ATGK) için bir risk faktörü olup olmadığının değerlendirilmesi, ATGK izlenen kadınlarda nitrik oksid (NO) seviyeleri ile eNOS gen polimorfizmleri arasındaki ilişkinin ortaya konulması.

Gereç ve Yöntemler: Bu çalışmaya 120 Türk kadını dört grup halinde dahil edilmiştir. Bu kadınlardan 30'u ATGK izlenen ilk trimester gebeliği bulunan kadın (Grup I), 30'u hiç abortusu bulunmayan, ilk trimester gebeliği bulunan multipar kadın (Grup II), 30'u ATGK hikayesi bulunan gebe olmayan kadın, geri kalan 30'u ise hiç abortus hikayesi bulunmayan sağlıklı multipar kadın (Grup IV) dır. Dört grubun iki polimorfizminin analizi PCR ve/veya PCR-RFLP metodları kullanılarak gerçekleştirilmiş ve NO seviyeleri spektrofotometrik olarak ölçülmüştür.

Bulgular: Gebe hasta grubunda NO seviyeleri istatistiksel olarak anlamlı ölçüde azalmış olarak izlenirken, gebe olmayan hasta grubunda NO seviyeleri anlamlı ölçüde artmış olarak izlenmiştir. Hasta ve kontrol grupları arasında VNTR 4/eNOS genotipi açısından fark saptanmazken, Glu298Asp/eNOS genotip sıklığı açısndan istatistiksel olarak sınırda anlamlı ölçüde bir fark saptanmıştır. Tüm gruplarda NO seviyeleri ile Glu298Asp/eNOS veya VNTR 4/eNOS genotipleri arasında bir korelasyon izlenmemiştir.

Sonuç: Türk toplumunda ATGK izlenen gebelerde eNOS geninin Glu298Asp polimorfizmleri kişisel bir risk faktörü olabilir. ATGK patofizyolojisinde NO yolaklarının yerinin ortaya konulabilmesi için yeni çalışmalara ihtiyaç vardır.

(J Turkish-German Gynecol Assoc 2011; 12: 234-8)

Anahtar kelimeler: Açıklanamayan tekrarlayan gebelik kayıpları, nitrik oksit, gen polimorfizmleri

Geliş Tarihi: 28 Ağustos 2011

Kabul Tarihi: 11 Eylül 2011

Available Online Date: 28 September, 2011

Address for Correspondence: Ebru Öztürk, Department of Obstetrics and Gynecology, Faculty of Medicine, Gaziantep University, Longer Road Kilis, Şahinbey Application and Research Hospital, 27310, Şahinbey, Gaziantep, Turkey Phone: +90533 3441702 e.mail: ebruozturkarslan@yahoo.com (c) Copyright 2011 by the Turkish-German Gynecological Education and Research Foundation - Available online at www.jtgga.org doi:10.5152/jtgga.2011.48 


\section{Introduction}

Recurrent miscarriage (RM), which is defined as 3 or more consecutive pregnancy losses before 20 weeks of gestation, affects $0.5 \%-2 \%$ of women in the reproductive age group (1). Although chromosomal and uterine abnormalities, thyroid dysfunction, coagulation and immunological alterations cause RM, 50\%-60\% of recurrent pregnancy losses are idiopathic (2).

Nitric oxide (NO), which is synthesized from L-arginine in endothelial cells by endothelial nitric oxide synthase (eNOS), provides a tonic dilator tone and regulates the adhesion of white blood cells and platelet aggregation. The NO pathway activation has been clearly demonstrated during normal pregnancy (3). It has been shown that, in the early stage of pregnancy, trophoblasts express high amounts of eNOS activity and placental production of gonadotrophic hormone is modulated by eNOS expressions (4). In an animal model, it was demonstrated that placental NO production mediated lipopolysaccharide induced abortion (5).

In the literature there are some reports on the association between eNOS gene polymorphisms and IRM. However, the results of these studies have been controversial among different ethnic groups (6-11).

In this study we aimed to determine whether eNOS gene polymorphisms are associated with an increased risk for IRM in the Turkish population and to evaluate the association between NO levels and eNOS gene polymorphisms in women with IRM. This study has focused on two functional variants of eNOS gene: a variant $\mathrm{G}$ to $\mathrm{T}$ conversion at nucleotide position 894 resulting in the replacement of glutamic acid with aspartic acid at codon 298 (Glu298Asp) and a variant variable number of $27 \mathrm{bp}$ tandem repeats in intron 4 (VNTR intron 4).

\section{Material and Methods}

\section{Subjects}

The protocol of this prospective controlled study was approved by the Ethics Committee for Clinical Research of Gaziantep University. Subjects were selected among women attending the Obstetrics and Gynecology Department of Gaziantep University. One hundred twenty Turkish women living in southeastern Anatolia were enrolled in this study in four groups. Because of increasing of NO production in pregnancy, NO levels of patients were compared with pregnant and non pregnant control groups which were Group II and Group IV respectively.

Group I consisted of 30 pregnant women in the first trimester with a history of IRM, and Group II consisted of 30 multipara pregnant women in the first trimester with no history of abortion. Group III consisted of 30 non-pregnant women with a history of IRM, Group IV consisted of 30 multipara non-pregnant women with no history of abortion.

IRM was defined after all the known causes were excluded by routinely performed investigations, including hysterosalpingography or sonohysterography, karyotype analysis, measurement of anticardiolipin antibody (IgG and IgM), lupus anticoagulant and thyroid stimulating hormone. Women with multiple pregnancy, or any concurrent medical complications before or developing during pregnancy, such as diabetes mellitus or inflammatory diseases, were excluded from the study. Smoking and alcohol or any drug use were also considered exclusion criteria.

\section{Genotyping Procedure \\ DNA isolation}

Genomic DNA was extracted from EDTA-treated peripheral venous blood using the salting-out method (13).

eNOS/Glu298Asp genotyping

A polymerase chain reaction (PCR) was used to amplify a 206 bp fragment. The resulting fragment was digested with MboI restriction endonuclease (Invitrogen,Carlsbad, CA, USA) overnight at $37^{\circ} \mathrm{C}$. Digestion was resolved on $3 \%$ agarose gel and visualized using ultraviolet light. The $206 \mathrm{bp}$ PCR products had a consistent restriction site resulting in a $119 \mathrm{bp}$ and an 87 bp fragment. Twenty percent of the samples were duplicated as an internal quality control to avoid sampling or reading errors (14).

\section{eNOS /VNTR intron 4 genotyping}

Primers were designed to amplify a $393 \mathrm{bp}$ and/or $420 \mathrm{bp}$ segment of the eNOS intron 4 VNTR region containing the microsatellite repeat sequence (14). The products were then separated on $4 \%$ NuSieve GTG agarose. The experimental process was repeated twice for each sample.

\section{Measurement of NO Levels}

NO released by the cells was measured in the plasma as nitrite/ nitrate, by the Griess reaction, after incubation of plasma samples with copperized cadmium (Cd) granules to convert $\mathrm{NO}_{3}$ to $\mathrm{NO}_{2}$. Griess reagent $(1 \mathrm{ml}$ of $1 \%$ sulfanilamide, $0.1 \%$ naphtylethylenediamine hydrochloride and $2.5 \%$ phosphoric acid; Sigma Chemical Co.) was then added to $1 \mathrm{ml}$ of supernatant (12). The absorbance was read at $545 \mathrm{~nm}$ after $30 \mathrm{~min}$ of incubation. Standard curves were prepared with known concentrations (1-100 $\mu \mathrm{mol} / \mathrm{L})$ of sodium nitrite. The results were given in $\mu \mathrm{mol} / \mathrm{L}$.

\section{Statistical Analysis}

Data were analyzed using SPSS for Windows version 13.0; (SPSS, Chicago, IL, USA). Statistical significance of the differences between the patient and control groups was estimated by logistic regression analysis. The Hardy-Weinberg equilibrium (HWE) was used to calculate estimated genotype frequency and experienced genotype frequency. A p value less than 0.05 was considered statistically significant.

\section{Results}

There was no significant difference between the groups studied in terms of maternal age and BMI. There was no significant difference between Group I and Group II in terms of gestational age.

Genotype frequency of eNOS Glu298Asp and VNTR intron 4 polymorphisms of patients who had IRM (Group I+III) and controls who had no abortion (Group II+IV) are presented in Table 2. There was no deviation from HWE between the patient 
and control groups in terms of Glu298Asp and VNTR Intron 4 in eNOS (Table 1). While there was no significant difference in patients with IRM in terms of eNOS/VNTR intron 4 genotype frequency, a marginally significant difference was determined in patients with IRM in terms of eNOS/Glu298Asp genotype frequency $(p=0.055)$. G/G homozygotes of Glu298Asp among IRM groups were marginally significantly frequent (Table 1).

NO levels were significantly different between Group I and Group II $(p=0.001)$; Group III and Group IV $(p=0.004)$ (Figure 1).

There was no association between NO levels and Glu298Asp/ eNOS or VNTR 4/eNOS genotypes in any of the groups (Table 2).

\section{Discussion}

Despite extensive researches to explain the causative effects of RM, about $50 \%-60 \%$ of recurrent pregnancy losses are still idiopathic (15-17). Endothelial damage, impaired placental vascularization and resultant oxidative stress have been proposed to play a role in the pathophysiology of IRM (2). eNOS has been regarded as the source of endothelial NO, which has a critical role in vascular physiology and impaired placental vascularization.

Even though extensively different eNOS gene variants have been demonstrated, functional variation in the eNOS gene has yet to be completely characterized (18). This study has focused on two functional variants: Glu298Asp and VNTR intron 4 polymorphisms of eNOS gene. This is the first study to evaluate the association between eNOS polymorphisms with IRM in a Turkish population.

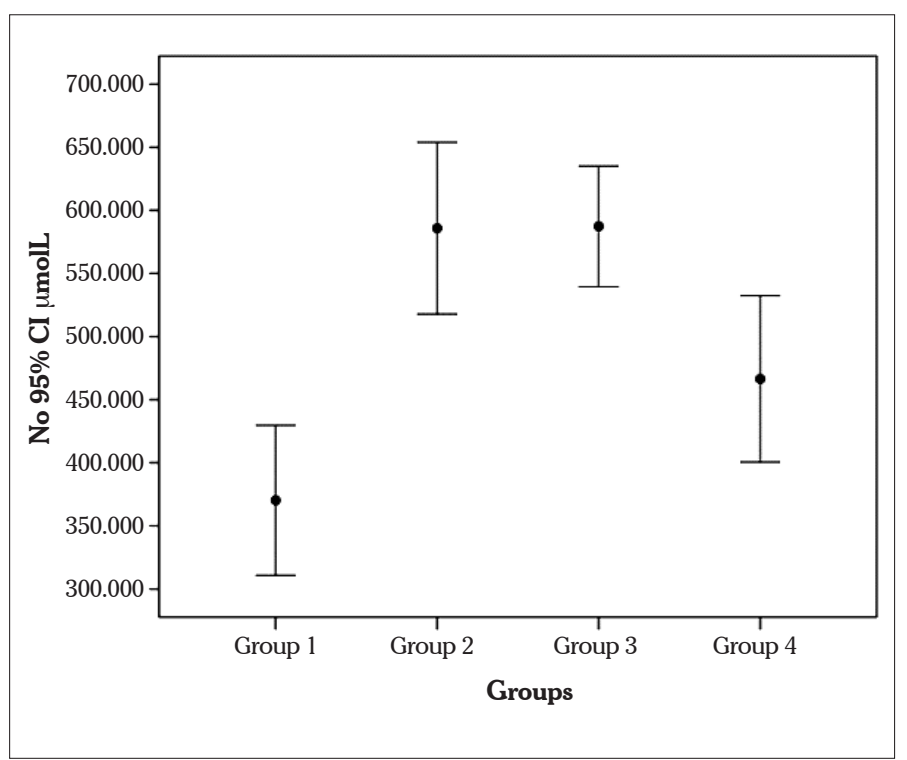

Figure 1. Comparison of Nitric Oxide Levels between patients with Idiopathic Recurrent Miscarriage (IRM) and healthy controls

Table 1. Comparison of eNOS/VNTR intron 4 and eNOS/Glu298Asp gene polymorphisms frequencies between patients with Idiopathic Recurrent Miscarriage (IRM) and healthy controls

\begin{tabular}{|c|c|c|c|c|c|c|}
\hline & Genotypes & $\begin{array}{c}\text { IRM } \\
(n=60)\end{array}$ & $\begin{array}{l}\text { Control } \\
(n=60)\end{array}$ & OR* & $95 \% \mathrm{CI}$ & P Value \\
\hline \multirow[t]{2}{*}{$\begin{array}{l}\text { Glu298Asp } \\
\text { n (\%) }\end{array}$} & $\begin{array}{c}\mathrm{GG} \\
\text { (reference) }\end{array}$ & $42(70.0)$ & $28(46.7)$ & & & \\
\hline & $\mathrm{GT}+\mathrm{TT}$ & $18(30.0)$ & $32(36.7)$ & 2.743 & $0.980-7.675$ & $0.055^{*}$ \\
\hline HWE $p$ & & 0.287 & 0.314 & & & \\
\hline \multirow{3}{*}{$\begin{array}{l}\text { VNTR Intron } 4 \\
\mathrm{n}(\%)\end{array}$} & AA & $38(63.3)$ & $54(79.4)$ & 0.469 & $0.071-3.084$ & 0.431 \\
\hline & $\mathrm{AB}$ & $16(26.7)$ & $10(14.7)$ & 0.469 & $0.071-3.084$ & 0.952 \\
\hline & $\begin{array}{c}\text { BB } \\
\text { (reference) }\end{array}$ & & $6(10.0)$ & $4(5.9)$ & & \\
\hline HWE $p$ & & 0.309 & 0.272 & & & \\
\hline
\end{tabular}

Table 2. Correlation of eNOS/VNTR intron 4 and eNOS/Glu298Asp gene polymorphisms and nitric oxide levels

\begin{tabular}{|l|c|c|c|c|c|}
\hline Nitric Oxide Levels & Genotypes & N & Mean & Std. Deviation & p value \\
\hline \multirow{3}{*}{ eNOS/Glu298Asp } & GG & 70 & 529.39 & 159.12 & 0.395 \\
\cline { 2 - 6 } & GT & 42 & 474.17 & 141.80 & 241.41 \\
\cline { 2 - 6 } & TT & 8 & 552.47 & 167.15 & 0.302 \\
\hline \multirow{3}{*}{ eNOS/ VNTR 4 } & AA & 88 & 519.32 & 150.88 & 88.29 \\
& AB & 33 & 462.00 & 586.38 & \\
\hline
\end{tabular}


In the literature, there are some reports on the association between eNOS gene polymorphisms and IRM. However, the results of these studies have been controversial among different ethnic groups.

Although Tempfer et al. demonstrated an association between VNTR intron 4/eNOS polymorphisms and IRM, in Austria (6), Karvela et al. (10) showed no association between VNTR intron 4 polymorphisms in eNOS gene and IRM in Greece. Our results were similar to those of Karvela et al., with no association between VNTR intron 4/eNOS polymorphisms and IRM in the Turkish population. In contrast to Karvela et al., we observed a marginally significant association between Glu298Asp/eNOS gene polymorphisms and IRM.

In this study we evaluated NO levels in four groups. To the best of our knowledge this is the first study evaluating both NO levels and eNOS gene polymorphisms with IRM simultaneously in the English literature.

Interestingly we observed statistically significant decreased NO levels in pregnant patient groups when elevated NO levels were measured in non pregnant patient groups and we demonstrated no association between NO levels and Glu298Asp/eNOS or VNTR 4/eNOS genotypes in any of the groups.

Defective placentation and resultant oxidative stress are believed to be largely responsible for preeclampsia and early pregnancy loss (19). In the literature, although some studies have demonstrated elevated NO levels, others have showed decreased NO levels in preeclampsia (20-22). This difference could be the result of complexity of NO pathways. Although in the past, it was believed that the increase in NO output was simply a result of eNOS expression, today it is known that the process of NO is more complex and flexible. Recent studies suggest that pregnancy-associated changes in NO output occur through reprogramming at the level of post-receptor cell signaling (23). The difference between pregnant and non pregnant groups in this study could be explained with reprogramming at the level of post-receptor cell signaling.

The results of our study suggest that impaired placental NO production play a key role in the pathophysiology of IRM and elevated NO levels in the non pregnant patient group could be a maternal response to compensate for placental deficiency. Indeed, recently Raffaelli et al demonstrated elevated NO production by platelets in patients with recurrent spontaneous miscarriage (24). This kind of maternal reponse could be persistant after pregnancy.

In conclusion, Glu298Asp polymorphism in the eNOS gene could be an intriguing factor that modulates an individual's risk of IRM in the Turkish population. However, further studies to explain the role of NO pathway in the pathophysiology of IRM are needed.

\section{Conflict of interest}

No conflict of interest was declared by the authors.

\section{References}

1. Wilcox AJ, Weinberg CR, O'Connor JF. Incidence of early loss of pregnancy. N Engl J Med 1988; 319: 189-94. [CrossRef]
2. Gupta S, Agarwal A, Banerjee J, Alvarez JG. The role of oxidative stress in spontaneous abortion and recurrent pregnancy loss: a systematic review. Obstet Gynecol Surv 2007; 62: 335-47. [CrossRef]

3. Lopez-Jaramillo P, Narvaez M, Calle A et al. Cyclic guanosine 3,5 monophosphate concentrations in pre- eclampsia: Effects of hydralazine. Br J Obstet Gynaecol 1996; 103: 33-8. [CrossRef]

4. Sanyal M, Nag TC, Das C. Localization of nitric oxide synthase in human trophoblast cells: role of nitric oxide in trophoblast proliferation and differentiation. Am J Reprod Immunol 2000; 43: 70-7. [CrossRef]

5. Haddad EK, Duclos AJ, Baines MG. Early embryo loss is associated with local production of nitric oxide by decidual mononuclear cells. J Exp Med 1995; 182: 1143-51. [CrossRef]

6. Tempfer C, Unfried G, Zeillinger R, Hefler L, Nagele F, Huber JC. Endothelial nitric oxide synthase gene polymorphism in women with idiopathic recurrent miscarriage. Hum Reprod 2001; 16: 1644-7. [CrossRef]

7. Hefler LA, Tempfer CB, Bashford MT, Unfried G, Zeillinger R, Schneeberger $\mathrm{C}$, et al. Polymorphisms of the angiotensinogen gene, the endothelial nitric oxide synthase gene, and the interleukin-lbeta gene promoter in women with idiopathic recurrent miscarriage. Mol Hum Reprod 2002; 8: 95-100. [CrossRef]

8. Suryanarayana V, Rao L, Kanakavalli M, Padmalatha V, Deenadayal $\mathrm{M}$, Singh L. Recurrent early pregnancy loss and endothelial nitric oxide synthase gene polymorphisms. Arch Gynecol Obstet 2006; 274: 119-24. [CrossRef]

9. Zammiti W, Mtiraoui N, Mahjoub T. Lack of consistent association between endothelial nitric oxide synthase gene polymorphisms, homocysteine levels and recurrent pregnancy loss in Tunisian women. Am J Reprod Immunol 2008; 59: 139-45. [CrossRef]

10. Karvela M, Papadopoulou S, Tsaliki E, Konstantakou E, Hatzaki A, Florentin-Arar L, et al. Endothelial nitric oxide synthase gene polymorphisms in recurrent spontaneous abortions. Arch Gynecol Obstet 2008; 278: 349-52. [CrossRef]

11. Al Sallout RJ, Sharif FA. Polymorphisms in NOS3, ACE and PAI-1 genes and risk of spontaneous recurrent miscarriage in the Gaza Strip. Med Princ Pract 2010; 19: 99-104. [CrossRef]

12. Granger DL, Taintor RR, Boockvar KS, Hibbs JB Jr. Measurement of nitrate and nitrite in biological samples using nitrate reductase and Griess reaction. Methods Enzymol 1999; 268: 142-51. [CrossRef]

13. Miller SA, Dykes DD, Polesky HF. A simple salting out procedure for extracting DNA from human nucleated cells. Nucleic Acids Res 1988; 16: 1215. [CrossRef]

14. Erciyas K, Pehlivan S, Sever T, et al. Endothelial nitric oxide synthase gene polymorphisms associated with periodontal diseases in Turkish adults. J Biotechnol 2010; 9: 3042-7.

15. Zeteroglu S, Ustun Y, Engin Ustun Y, Zeteroglu U, Karayel M. Serum folic acid levels in women with recurrent early pregnancy loss. Artemis, 2003;4: 36-7.

16. Tripathi P, Naik S, Agrawal S. HLA-E*0101 associated with recurrent spontaneous abortion. J Turkish-German Gynecol Assoc 2007; 8: 278-82.

17. Saatci C, Oner G, Tasdemir S, Kiraz A, Ozkul Y, Dündar M, et al. Parental karyotype and genetic markers for thrombophilia in recurrent miscarriage. J Turkish-German Gynecol Assoc 2008; 9: 139-43.

18. Casas JP, Cavalleri GL, Bautista LE, Smeeth L, Humphries SE, Hingorani AD. Endothelial nitric oxide synthase gene polymorphisms and cardiovascular disease: A HuGE review. Am J Epidemiol 2006; 164: 921-35. [CrossRef]

19. Harma M, Harma M. Defective placentation and resultant oxidative stress play a similar role in complete hydatidiform mole to that in preeclampsia and early pregnancy loss. Med Hypotheses 2006; 66: 100-2. [CrossRef]

20. Teran E, Chedraui P, Vivero S, Villena F, Duchicela F, Nacevilla L. Plasma and placental nitric oxide levels in women with and with- 
out pre-eclampsia living at different altitudes. Int J Gynaecol Obstet 2009; 104: 140-2. [CrossRef]

21. D'Anna R, Baviera G, Corrado F, Crisafulli A, Ientile R, Buemi M, et al. Neurokinin $B$ and nitric oxide plasma levels in pre-eclampsia and isolated intrauterine growth restriction. BJOG 2004; 111 : 1046-50. [CrossRef]

22. Mao D, Che J, Li K, Han S, Yue Q, Zhu L, et al. Association of homocysteine, asymmetric dimethylarginine, and nitric oxide with preeclampsia. Arch Gynecol Obstet 2010; 282: 371-5. [CrossRef]
23. Boeldt DS, Yi FX, Bird IM. eNOS activation and NO function: Pregnancy adaptive programming of capacitative entry responses alters nitric oxide (NO) output in vascular endothelium-new insights into eNOS regulation through adaptive cell signaling. J Endocrinol 2011; 210: 243-58. [CrossRef]

24. Raffaelli F, Nanetti L, Vignini A, Mazzanti L, Giannubilo SR, Curzi $\mathrm{CM}$, et al. Nitric oxide platelet production in spontaneous miscarriage in the first trimester. Fertil Steril 2010; 93: 1976-82. [CrossRef] 